\title{
THE AGGREGATE AND RESIDENTIAL ELECTRICITY DEMAND IN INDONESIA $^{1}$
}

\section{PERMINTAAN TENAGA LISTRIK NASIONAL DAN SEKTOR RUMAH TANGGA DI INDONESIA}

\author{
Muhammad Zulfizal Arnaz \\ Ditjen Ketenagalistrikan, Kementerian Energi dan Sumber Daya Mineral, m.zulfizal.a@gmail.com;
}

\begin{abstract}
This paper presents an empirical analysis on electricity demand in Indonesia applying a double-log demand equation for aggregate and residential. This proposes static and dynamic models employing fixed effects and bias-corrected least square dummy variable estimators, respectively. Particular attention is paid to the effects of income, price, and the numbers of customers. The paper concludes that all regressors function as the determinants of electricity consumption. Price elasticities are inelastically negative as expected, and further, profound inelastic for residential. Meanwhile, income level and the number of customers are quite elastic for both models. In addition, interregional analysis reports the differential impacts of the price on energy consumption between Java Bali and non-Java Bali regions, showing less responsiveness of consumption to price in Java Bali. The long-run estimates give information on modest values of price elasticities for aggregate and residential. From an energy policy point of view, electricity price would be moderately effective in achieving efficiency and conservation programs. On the other hand, it gives an economic rationale for tariff adjustment and regionbased tariff restructuring.
\end{abstract}

Keywords: electricity demand, panel data, inter-region analysis, static and dynamic model JEL Classification: C230, O180, Q470

\begin{abstract}
Abstrak
Studi ini menyajikan analisis empiris terhadap permintaan energi listrik yang disimulasikan pada data konsumsi agregat dan sektor rumah tangga. Untuk mempelajari permintaan listrik digunakan model statik dengan menerapkan fixed effects dan model dinamik melalui pendekatan metode estimasi bias-corrected least square dummy variable (LSDV). Dengan menggunakan data pengeluaran, tarif listrik, dan jumlah pelanggan sebagai variabel bebas, hasil simulasi menunjukkan seluruh variabel signifikan mempengaruhi tingkat konsumsi listrik baik pada tingkat nasional maupun rumah tangga. Kenaikan tarif listrik mempunyai pengaruh secara negatif pada konsumsi energi meskipun relatif kecil, bahkan lebih kecil pada sektor rumah tangga. Di sisi lain, tingkat ekonomi dan jumlah pelanggan signifikan berdampak dalam mendorong tingkat konsumsi listrik. Selain itu, ditemukan pula perbedaan besaran efek perubahan tarif terhadap konsumsi listrik antara daerah di Jawa-Bali dan luar Jawa-Bali, yaitu efek tarif listrik terhadap konsumsi listrik di Jawa-Bali lebih kecil dibandingkan daerah lainnya. Hasil dari model dinamik menunjukkan bahwa dalam jangka panjang pengaruh tarif listrik terhadap konsumsi listrik semakin besar, baik pada tingkat nasional maupun rumah tangga. Dari sisi kebijakan, tarif listrik secara umum kurang memberikan dampak yang besar dalam upaya konservasi energi, namun di sisi lain memberikan landasan untuk penyesuaian tarif listrik bahkan penerapan tarif listrik regional.

Kata kunci: konsumsi listrik, data panel, analisa antar wilayah, model statik dan dinamik Klasifikasi JEL: C230, O180, Q470
\end{abstract}

\footnotetext{
${ }_{1}$ The study is part of author's Master thesis for National Graduate Institutes for Policy Studies (GRIPS)
} 


\section{INTRODUCTION}

The reliable estimates of price and income elasticities of electricity demand have proved to be valuable instruments for policymakers as a basis of setting up appropriate energy policy regarding electricity sector management and planning (Dergiades \& Tsoulfidis, 2008). In general, the electricity supply industry is a highly capital-intensive venture. In particular, power stations as one of the main elements absorb high investment for construction and takes relatively long lead times before becoming operational. Due to the practically unstorable nature of electricity, it is obviously vital to attain an adequate supply in order to meet the increasing demand. As a result, rigorous analysis of the determinants of electricity demand is essential for the design of an effective energy policy to deal with energy security issues, such as energy supply projection.

The ideal empirical model expresses electricity demand as a function of its own price, the price of a substitute source of energy, real income, prices of electrical appliances and machineries, and other factors that could impact consumer preferences, such as temperatures. However, most studies model electricity demand as a function of the two main determinants, i.e., own price and income, due to the availability of data. In addition to price and income, several papers utilize cross-price and some countryspecific characteristics, such as population, temperature, and urbanization. Most studies conclude that energy is a basic necessity of life. However, it is obvious that the results and implications of research practically rely on the primary variables, the econometric methods, the period of data, and the country-specific characteristics.

In the backdrop of electricity shortages in some regions, this study attempts to determine the electricity demand in Indonesia based on provincial data. The main objective of this paper is to empirically analyze the electricity demand in Indonesia during the period 2000-2010 for aggregate and residential sectors. This study proposes a static model to determine the price and income elasticity of electricity demand and brings together the estimates of the long-run trend in a dynamic model to develop a possible general explanation in the long-run framework. Furthermore, this study attempts to evaluate the differential impacts of price and income on electricity consumption by inter-regional analysis, particularly between Java Bali and non-Java Bali provinces.

The remainder of the paper is organized as follows. Section 2 describes the literature review. Section 3 presents the data and methodology. Section 4 conducts a discussion on estimation results. Section 5 concludes, and finally, Section 6 gives a possibility of policy implications.

\section{Electricity in Indonesia}

By looking at the demand and supply side, electricity demand has surged by $86 \%$ in the last decade; however, electricity supply has only increased by $29 \% .^{2}$ As a result, most regions exhibited electricity shortages due to undersupply of power. To enhance the power capacity, the government has made efforts through Independent Power Producer (IPP) projects initialized in the 1990s and an acceleration program through the power generation project of $10,000 \mathrm{MW}{ }^{3}$ It is predicted that the acceleration program will take effect in 2011. Figure 1 represents a condition of electricity supply from 2000 to 2010 in comparison with the demand. In a period of 2000-2010, as intended in this study case, it is obvious that a electricity provision in terms of power plant construction was lagging behind demand growth.. Therefore, a better planning ahead is necessary in order to secure power supplies. However, later we can see an accelerated supply as a result of the acceleration provision program incorporating

\footnotetext{
${ }^{2}$ Electricity supply in terms of the capacity of power generation obtained from Power Supply Business Plan (Rencana Umum Penyediaan Tenaga Listrik/ RUPTL) 2013-2022, PT PLN. However, the new RUPTL of PLN using the assumption of an annual economic growth of $6,86 \%$ electricity supply, in terms of generation capacity, is planned to an average annual growth of $7,3 \%$ or grow $87,8 \%$ from 2018 $(59,6 \mathrm{GW})$ to $2027(112 \mathrm{GW})$. The growth of generation capacity in the newly RUPTL is similar to the growth of demand which should has been provided in the period of 2000-2010 as in the case of this study.

3 The acceleration program Step 1 was stipulated by Presidential Regulation No. 71 Year 2006.
} 


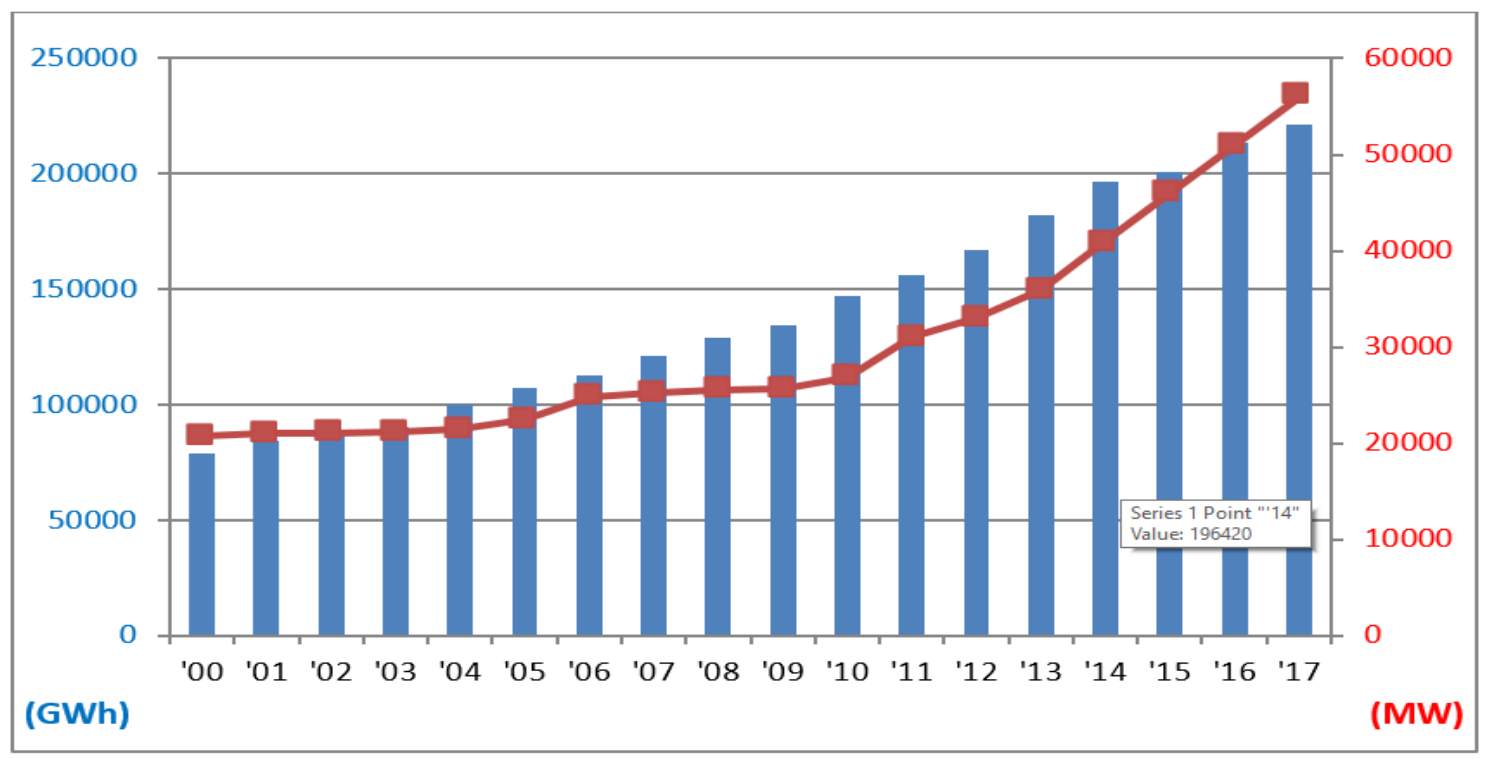

Figure 1. Electricity supply and demand

Source: assembled from data of PLN Annual Report

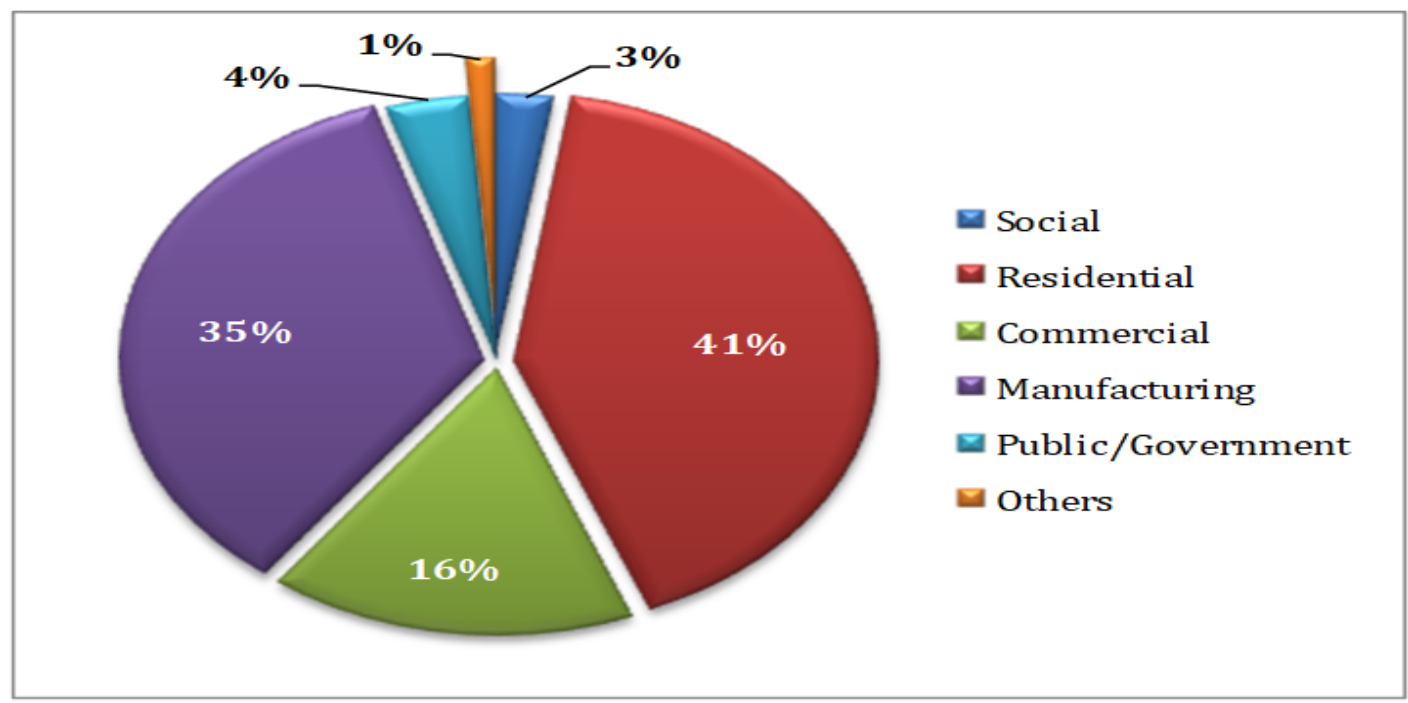

Figure 2. The share of electricity consumption by customer's group

Source: PLN Annual Report (2010)

private parties to participate in national electricity provision.

On the other hand, figure 2 shows the shares of consumption by groups of customers, e.g., residential, commercial, manufacturing, and others. In fact, residential has the largest number of customers (39 million), which is 93\% of the total consumers (PLN, 2010). From Figure 2, it is clear that residential consumption accounts for almost half of the total consumption. Therefore, the residential sector significantly drives electricity demand in Indonesia.
Nevertheless, the electrification rate (ER) in the period of 2000-2010 showed that there were still many households without electricity access located generally in outer Java Island.. ${ }^{4}$ In 2000, about half of the total households were connected to the power grid. A decade later, this ratio reached to about two-thirds of all households with access to electricity service. This means, however, one-third of the population, or about 19 million households, do not have access to electricity services yet. To tackle this issue, the government has

${ }^{4} \mathrm{RE}$ is the ratio of households having electricity access to the total number of households. 


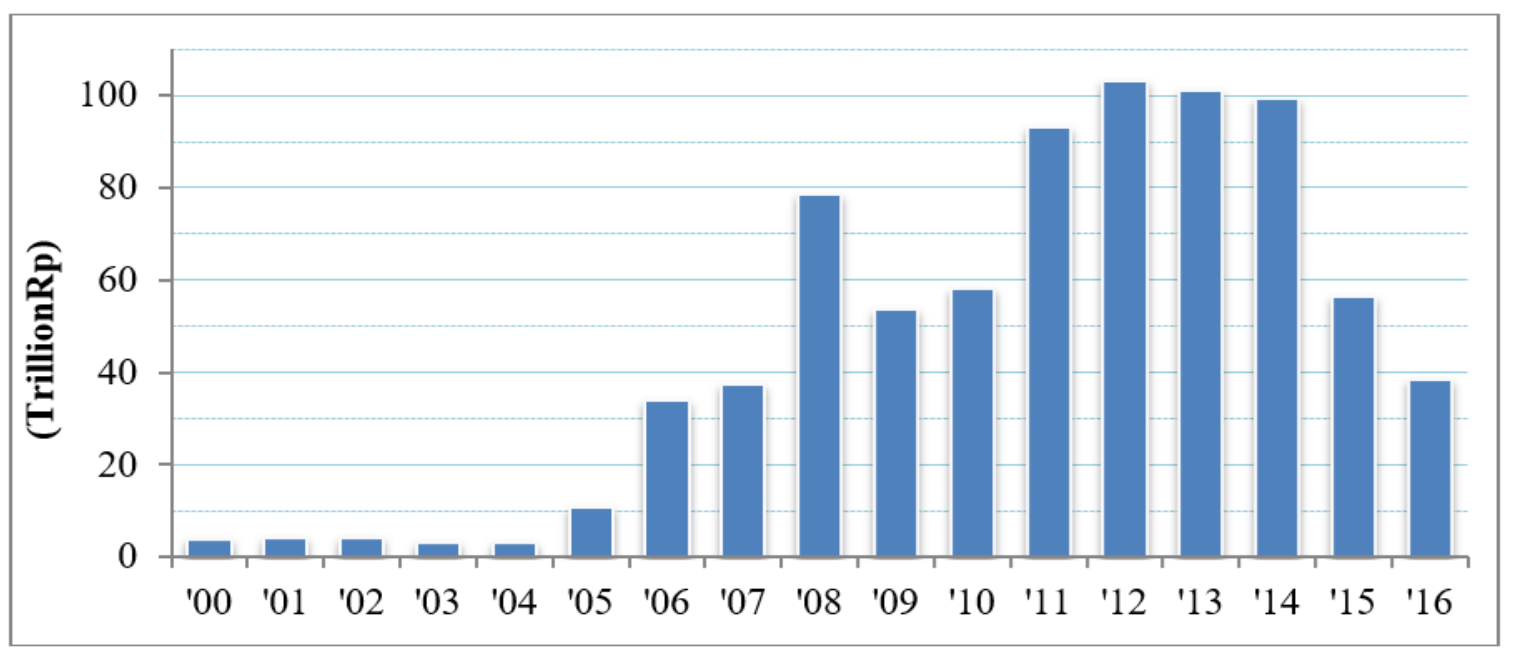

Figure 3. Subsidy allocation 2000-2016

Source: Examination Report on electricity subsidy of BPK RI

embarked some programs in an effort to boost ER, with a target of the whole population being connected to power lines by 2025 , which resultantly, will further drive energy consumption in the future. ${ }^{5} \mathrm{Up}$ to $2017 \mathrm{RE}$ has reached a point of $95,35 \%$ leading an optimistic view of the $100 \%$ of targeted RE will be achieved.

According to Law No. 30 of 2009, the government has the responsibility to provide electricity subsidy, particularly for low-income customers. The current subsidy mechanism is based on the gap between the electricity tariff imposed on consumers and the electricity production cost borne by electricity producers. ${ }^{6}$ In fact, the electricity tariff structure is regulated, and electricity price was raised annually from 2000 to 2004 and again in 2010. On the other hand, the prices of energy inputs substantially increase over time, keeping pace with energy market prices, e.g. coal, oil, gas; as a result, the gap between tariff and production cost becomes wider year by year. Inevitably, this leads to an increased amount of subsidy allocated by the government in the last decade. Figure 3 graphs subsidy allocations in this period. Electricity subsidy reform has been starting from 2013 which electricity tariff for large

\footnotetext{
5 As targeted in General Plan of Electricity (Rencana Umum Ketenagalistrikan/RUKN) 2010-2029.

${ }^{6}$ Initialized through Ministry of Finance Regulation (MFR) no. 117/2005 and lately revised by MFR no. $111 / 2007$. Before 2005, the subsidy was targeted for customers with low power contracts.
}

industrial and business are adjusted to its economical level or at the cost of electricity supply. This tariff increase was further applied for large residential and medium industrial and business which eventually applied by a tariff adjustment mechanism from 2014. The subsidy allocation has substantially increased from Rp. 3,93 trillion (US\$ 410 million) in 2000 to over Rp. 58,11 trillion (US\$ 6.5 billion) in 2010 then reached a peak at Rp. 103.33 billion (US\$ 10,9 billion) in 2012 . It is noteworthy that a substantial increase in subsidy has been recorded since 2005, as compensation mechanism based on gap between tariff and production cost, was first implemented. Another issue arising from imposing the current subsidy mechanism is that high-income customers will receive subsidies since they are most likely high energy-consumers. Hence, this mechanism does not fit to the basic concept that subsidies should be provided to low-income customers as stipulated in Law on Electricity. ${ }^{7}$

\section{LITERATURE REVIEW}

Theoretically, many studies have modeled the electricity demand function as derived demand based on the firm and household production theory. Beenstock, Ephraim, and Dan (1999) suggest that the consumers allocate resources for the consumption of competing goods after deciding total consumption allocations, thus reflecting

\footnotetext{
${ }_{7}$ Article 4 of Law 30 of 2009 on Electricity
} 
derived demand. According to Filippini and Pachauri (2004) and Narayan, Smyth, and Prasad (2007), electricity is one of the input factors added to the production function of the economic agent for the production process, thus as a derived demand. In a theoretical basis, Anderson (1973), Filippini (1999), and Alberini and Filippini (2011) explain the residential electricity demand function as a derived demand from its utility function. Households utilize electricity as an input for electrical appliances to produce commodities, such as cooking, conditioned rooms, and lighting.

However, it is noteworthy that the stock electrical appliances could not adjust instantaneously as the determinants of demand change. Since the electricity demand is derived from the use of electrical stocks, changes in the determinants of demand will lead to changes in the utilization rate in the short run and, further, in changes in the electrical stocks. For instance, in the short term, consumers adapt to an increased price by reducing the utilization of electrical appliances and machineries; however, in the long term, they can replace the existing electrical equipment with more efficient ones. In order to take into account this potential issue, a partial adjustment model may be employed in the long-run framework analysis, as adopted in Houthakker and Taylor (1970). This model assumes that the change in the log of actual demand between any two periods, period $\mathrm{t}$ and $\mathrm{t}-1$, is only the fraction of the difference between the log of actual demand in the desired (equilibrium) demand and that in period t-1. In general, consumers may partially adapt to a desired demand because of the existence of frictions, habit formation, costs involved in replacing the existing capital stock, and possible lack of information (Al-Faris, 2002).

There is extensive empirical literature examining energy demand functions. In an early study of energy demand, Houthakker (1951), estimating energy demand of residential consumers with a static model on cross-sectional data in the United Kingdom, finds that income and price elasticities are not so far from unity. Moreover, Pindyck (1979) reports that income level and energy price are significant as the determinants for energy demand for both developed and developing countries and gives evidence that price elasticity is very low, indicating a high degree of necessity in energy use, whereas income elasticity is about unitary, highlighting the responsiveness of income level on energy demand.

Furthermore, Dahl (2011), surveying energy demand literature, revealed that the price elasticity of electricity demand is inelastic at a median value of -0.14 (short run) and -0.37 (long run), while the median value of income elasticity is 0.30 (short run) and 0.88 (long run). The survey also showed that the coefficient of the lagged endogenous variable in dynamic models is about 0.66 at median value. Moreover, Brenton (1997), examining electricity demand across countries, found that the price elasticity of electricity demand in poor countries is the lowest, at -0.073 , followed by middle $(-0.695)$ and high-income countries $(-0.704)$, which indicates that price elasticities of energy in developing countries are lower than those of more advanced economies due to either a low degree of substitutability or a high degree of necessity.

In general, we can find that, for most developed countries, the price elasticity of energy demand is higher than that of developing countries; on the contrary, developed economies have relatively low income elasticity. A recent study of Krisnamurthy and Kristrom (2013), using survey data of OECD countries, provides a strong price responsiveness and weak income response in most advanced countries, even though the estimates of parameters vary at the state and country levels. In addition, the long-run estimates show that price and income elasticities are higher than those in the short run. Several research are selected to compare price and income elasticity across countries. ${ }^{8}$

A few studies on energy demand have been conducted for the case of Indonesia. In an early study, Pitt (1985), using firm-level data, reported that the price elasticity of industrial energy demand is inelastic ranging from -0.30 to -0.40 for most sectors. Ibrahim and Hurst (1990) found the elastic income

\footnotetext{
${ }_{8}$ See Table A in the Appendix for selected research.
} 
elasticity of aggregate energy demand at a value of 1.19. Moreover, Pesaran, Smith, and Akiyama (1998) studied energy demand at the aggregate, transportation, and residential sectors in developing countries using a dynamic panel estimation and supported that income elasticity is elastic, whereas price elasticity is inelastic in absolute terms for the case of Indonesia. A recent study of Saad (2009), using annual time series data over the period of 1973-2008 in the Underlying Energy Demand Trend (UEDT) model, analyzed aggregate energy demand at the aggregate and residential levels and found similar results of elastic income and inelastic price elasticity. The research showed that price $(-0.09)$ and income elasticity $(0.58)$ of residential energy demand were lower than those of aggregate data at -0.35 and 1.13 for price and income elasticity, respectively.

The aforementioned studies have investigated energy demand behavior for the case of Indonesia at the aggregate energy demand. This paper will attempt to examine price and income elasticity of the electricity demand for aggregate and residential data. In addition, complementary analysis of non-residential demand behavior is presented. For more in-depth evaluation, this study also specify the estimates of price and income elasticities between two main regions, namely, Java Bali and non-Java Bali. Using the period data of 2000-2010 at the provincial level, I propose two models, i.e., static and dynamic models. In the static model, the paper employs fixed effect (FE) estimators, while in the long-run framework analysis, this utilizes a corrected least square dummy variable (LSDVC) of Kiviets (1995).

\section{DATA AND METHODOLOGY}

\section{Data}

In this study, the model follows from conventional consumer demand analysis adopted to evaluate electricity demand behavior. As in most research, electricity demand is considered as a function of the main variables of income and own-price and some additional variables, e.g., cross-price, urbanization, and temperature. For this study, I employ a panel dataset into log-log functional form for both aggregate and residential demand models, specifying (1) a static model using fixed effects estimation and (2) a dynamic model based on a partial adjustment approach of electricity demand as follows, respectively:

$$
\begin{aligned}
& \ln E C_{i t}=\alpha+\beta \ln P_{i t}+\gamma^{\prime} \ln X_{i t}+\varepsilon_{i t} \\
& \ln E C_{i t}=\alpha+\beta \ln P_{i t}+\gamma^{\prime} \ln X_{i t}+\delta \ln E_{i t-1}+\varepsilon_{i t}
\end{aligned}
$$

where EC is the electricity consumption (in gigawatt hours), $\mathrm{P}$ denotes the real average electricity price (in constant 2000 rupiah/ $\mathrm{kWh}$ ), and $\mathrm{X}$ denotes the other explanatory variables. The paper introduces real gross domestic regional products (GDRP, in billions of constant 2000 rupiah) in order to control the effects of economic activity level among provinces and proposes the number of customers to control the effects of additional customers on electricity demand. A lagged-dependent variable of is included for the dynamic model specification. Finally, is the error term assumed to be white noise and normally and identically distributed. ${ }^{9}$

As supplementary analysis, I employ the model using non-residential data in order to analyze the electricity demand behavior of the other sectors, e.g., business and commercial. Initially, I am interested in evaluating the price and income of elasticity on demand for the industrial sector. However, due to limitations in the data source, I only simulate the model for non-residential data. This type of data is literally obtained by subtracting residential from aggregate data. It should be noticed that non-residential includes all customers other than residential. In 2010 the industrial sector contributed to about $60 \%$ of the total non-residential consumption, as compared to commercial with $27 \%$ and the others with $13 \%$. Thus, one may expect that this non-residential analysis may roughly capture a figure of electricity demand in the industrial sector; however, further research should be certainly performed for the precise estimates of industrial demand behavior.

These data were obtained from the Central Bureau of Statistics of Indonesia

\footnotetext{
${ }^{9}$ See Table $\mathrm{B}$ in the Appendix for detailed data sources.
} 
Table 1. Descriptive Statistics for Data Panel of 2000-2010

\begin{tabular}{|l|c|c|c|c|}
\hline \multicolumn{1}{|c|}{ Variables } & Mean & Std. Dev. & Min. & Max. \\
\hline Aggregate & & & & \\
Consumption (GWh) & 3390.0 & 6153.7 & 40.2 & 30720.9 \\
Price (Rp/kWh) & 351.9 & 72.5 & 201.8 & 546.8 \\
GDRP (billion 2000 Rp) & 54034.9 & 78705.8 & 1473.3 & 395664.5 \\
No. of customers & 1090506 & 1739354 & 47720 & 8206806 \\
\hline Residential & & & & \\
Consumption (GWh) & 1422.4 & 2227.2 & 29.0 & 11617.1 \\
Price (Rp/kWh) & 294.4 & 67.5 & 172.6 & 464.0 \\
GDRP (billion 2000 Rp) & 31569.9 & 49721.5 & 1230.8 & 243827.2 \\
No. of customers & 1081959 & 1665093 & 44315 & 7740066 \\
\hline
\end{tabular}

and annual electricity statistics of PT PLN. ${ }^{10}$ Table 1 presents descriptive statistics, giving information on the variables utilized in the model. ${ }^{11}$

In principle, income level determines the level of energy use. There are some channels linking energy consumption to income level. Firstly, electricity is an indispensable input into the production processes of firms; therefore, growth in GDP that induces output will further increase the use of electricity. Further, expansions to production will stimulate capital formation and accumulation of electricity-driven machinery and durable equipment. For households, electricity utilization is specified using the basic framework of household production theory, where energy is used as an input for appliances to produce the household commodities, e.g., lighting, air conditioning, cooked food, hot water, etc. Thus, rising income levels will encourage increased energy consumption for electrical appliances.

Furthermore, this study employs a variable of price using the average price term. Nordin (1976) argued that instead of average price, marginal price is the appropriate proxy for electricity price. It should be noted that employing the average price may induce the endogeneity problem since the average price level depends on the contracted power and the level of electricity consumption. However, as suggested by Shin (1985), for aggregate level, such as national data, the presence of a

\footnotetext{
${ }^{10}$ Due to the availability of data, of all 33 provinces, I use data of 32 provinces for aggregate model (combining Papua and West Papua) while data of 30 provinces is simulated for residential model (combining Papua and West Papua, Riau and Riau Islands, and West Sulawesi and South Sulawesi).

${ }^{11}$ Descriptive statistics for two regions are presented in Table $\mathrm{C}$ of the Appendix.
}

block tariff system mitigates the endogeneity problem. This assumption approach is also argued in Bernstein and Griffin (2006), Paul, Myers, and Palmer (2009), Alberini and Filippini (2011), and Blazquez, Boogen, and Filippini (2013). Moreover, Paul et al. (2010) argued that price can be regarded as exogenous because of regulated pricing. Hence, the average price of electricity is assumed as an exogenous variable in the paper. In addition, it is theoretically common to have a price level of substitutes, e.g., gas, kerosene, etc., in the demand behavior model. However, due to a lack of available data and in consideration of a limited degree of substitutability for electricity, we do not include any prices of substitutes for electricity.

Moreover, many studies incorporate some variables that vary across countries, such as population and temperature, considered as the determinants of the level of electricity consumption. In regard to a substantial number of people with no access to an electricity grid, the study takes into account the numbers of customers in order to control the effect of additional customers on the electricity consumption level. ${ }^{12}$ Accordingly, the additional customers on power grids will further induce the higher consumption level.

In the long-run view, it is worthwhile to note that since the equipment stock of electrical appliances and machineries cannot adjust easily to the long-run equilibrium, the actual electricity consumption may differ from the long-run equilibrium consumption. Therefore, the paper attempts to utilize a dynamic model by employing a partial adjustment mechanism for allowing this situation. To implement

\footnotetext{
${ }^{12}$ In 2010 , the electrification rate was about $72 \%$. According to RUKN 2012-2031, the government has a target of ER at $99 \%$ by 2022 .
} 
the dynamic specification model, this paper includes the lagged dependent variable as an explanatory variable. ${ }^{13}$

It should be noted that the model uses electricity consumption as the dependent variable and all the regressors in the form of natural logarithms; thus, the estimated coefficients are directly interpretable as demand elasticity.

\section{Methodology}

With regard to our purposes in this research, I will evaluate the demand behavior for electricity in both the static and dynamic models. For the static model, it is well-known to take into account unobserved heterogeneity in province-specific characteristics by using a Fix Effects (FE) or Random Effects (RE) model. Wooldridge (2009) argued that in some applications of panel data models, particularly most policy analysis using aggregated data, we cannot treat the samples as a random sample from a large population, e.g., states of provinces. Hence, employing FE model is much more satisfying, rather than RE model by assuming correlation between individual-specific, time-invariant behavior and the other explanatory variables. Similarly, Judson and Owen (1999) said that the fixed effects model is common and more appropriate for macroeconomic analysis. They argued that if the individual effect represents omitted variables, it is likely that these state-specific characteristics are correlated with the other regressors. However, it is customary to apply the Hausman test in deciding the appropriate model between FE and RE; therefore, the study also reports the results from the Hausman test.

Furthermore, interregional analysis is performed to estimate any spatial differences in the electricity demand by employing interactions terms between a regionindicator dummy variable (Java Bali) and the explanatory variables. These interaction terms allow the estimated parameters to vary based on the dummy variable and further determine whether elasticities differ across regional units. In regional level regressions, I estimate the model using panel data of the

\footnotetext{
${ }^{13}$ See Appendix for the derived partial adjustment process.
}

2000-2010 period from the 32 provinces as follows:

$$
\begin{aligned}
\ln E C_{i t}= & \alpha+\beta \ln P_{i t}+\gamma_{I N C} \ln I N C_{i t}+\gamma_{C U S T} \ln C_{U S T} T_{i t}+\beta^{\prime}(D * \\
& \left.\ln P_{i t}\right)+\gamma_{I N C}^{\prime}\left(D * \ln I N C_{i t}\right)+\gamma_{C U S T}^{\prime}\left(D * \ln C U S T_{i t}\right)+\varepsilon_{i t}(3)
\end{aligned}
$$

In accordance with the dynamic model, it is well known that applying a fixed effects model, as a lagged dependent variable included in the model, makes the estimates biased, particularly for $\mathrm{N}$ (individual dimension) large and finite $\mathrm{T}$ (time dimension). A seminal work of Nickell (1981) showed that the bias of the standard fixed and random effects estimators in the presence of lagged dependent variables is particularly severe when each panel has relatively few observations. This underlies the development of a variety of dynamic panel estimators, which present consistent but not necessarily efficient estimates of the model parameters.

The dynamic panel estimators can be classified typically into the group of instrumental estimators and the group of direct bias corrected estimators. Andersen and Hsiao (1982) proposed the first differenced 2SLS estimators, eliminating unobserved individual heterogeneity by first differencing, but this leads to autocorrelation with the error term. Arellano and Bond (1991) introduced GMM estimators (difference GMM). In order to determine the estimates, this method proposes to first-difference the model and uses the lagged levels of the endogenous explanatory variables as instruments. However, due to large sample properties of the GMM methods, this method will be biased in the small sample framework. As Blundell and Bond (1998) stated, with persistent data, differenced IV and GMM estimators suffer from small sample bias due to weak internal instruments. As a solution, they suggest another GMM estimator (system GMM) with first-differenced instruments for the equation in levels and instruments in levels for the differenced equation.

As an alternative, Kiviets (1995) proposed a method for a dynamic model based on a bias correction of the LSDV model. The approximation of the bias correction derived from the LSDV model when the errors were serially uncorrelated and the 
Table 2. The results of the Static Model Using FE

\begin{tabular}{|c|c|c|c|}
\hline & \multicolumn{3}{|c|}{ Dependent variable: lec } \\
\hline & Aggregate & Residential & Non residential \\
\hline lprice & $-0.1907 * * *$ & $-0.0869^{* * *}$ & $-0.4021^{* * *}$ \\
\hline \multirow{2}{*}{ linc } & $0.6077 * * *$ & $0.6743 * * *$ & $0.1853 * * *$ \\
\hline & $(0.083)$ & $(0.063)$ & $(0.058)$ \\
\hline lcust & $\begin{array}{l}1.0908 * * * \\
(0.095)\end{array}$ & $\begin{array}{l}0.9554 * * * \\
(0094)\end{array}$ & $1.1163 * * *$ \\
\hline \multirow[t]{2}{*}{ Constant } & $-12.4055 * * *$ & $-12.0837 * * *$ & $-5.0065^{* * *}$ \\
\hline & $\begin{array}{c}(0.622) \\
352\end{array}$ & $\begin{array}{c}(0.765) \\
320\end{array}$ & $\begin{array}{c}(1.036) \\
320\end{array}$ \\
\hline \multirow{3}{*}{$\begin{array}{l}\text { Observations } \\
\text { R-squared } \\
\text { No.of provinces } \\
\text { F-test } \\
\text { Hausman test: } \\
x_{2}= \\
\text { p-value }\end{array}$} & 0.997 & 0.997 & 0.995 \\
\hline & 890.63 & $\begin{array}{l}30 \\
999.76\end{array}$ & 488.89 \\
\hline & $\begin{array}{c}99.33 \\
0.0000\end{array}$ & $\begin{array}{l}383.91 \\
0.0000\end{array}$ & $\begin{array}{c}0.94 \\
0.8163\end{array}$ \\
\hline \multicolumn{4}{|c|}{ Notes: Standard errors in brackets } \\
\hline \multicolumn{4}{|c|}{$* * *, * *, *$ for $1 \%, 5 \%, 10 \%$ respectively } \\
\hline
\end{tabular}

regressors were strictly exogenous. Moreover, Judson and Owen (1999) performed Monte Carlo experiments to examine the relative performance of different panel data estimators in the presence of lagged dependent variables in panel datasets having dimensions more commonly encountered in macroeconomics. Based on their result, with aggregate data characterized by a $T$ value lower than or equal to 20 and an $\mathrm{N}$ value lower than or equal to 50, as in our data, the Kiviet (1995) estimators are the best choice. For the grounds of the exogeneity assumption of the explanatory variables and the moderate-sized panel dataset, this study will apply the bias-corrected LSDV method to estimate electricity demand behavior in the dynamic model.

\section{RESULT AND DISCUSSION}

This empirical study evaluates the aggregate and residential electricity demand in both static and dynamic models. In the former model, fixed effects specification is applied while the bias-corrected least square dummy variable is employed to estimate the latter model, including the lagged dependent variable as an explanatory variable.

\section{Static Model}

First of all, to examine the static model for a panel dataset, it is usual to apply FE and RE specification in order to take into account unobserved heterogeneity. This unobserved condition associates with the existence of unique, time-invariant, individual characteristics, which should not be correlated with other individual characteristics. Moreover, it is customary to apply the Hausman test in deciding the preferred technique between FE and RE; therefore, the test result is also presented. The results from the Hausman test for aggregate and residential data suggest that FE are preferred over random effects. In addition, by utilizing non-residential data, instead of using an RE model, as confirmed by the Hausman test, the result of an FE model is also presented due to practical consideration in the previous discussion on the methodology.

The results shown in Table 2 give information that all regressors have the expected signs and are statistically significant at the $1 \%$ confidence level, so all variables can be considered as the determinants of electricity consumption. Basically, the estimates report inelastic price elasticity and more elastic income elasticity of electricity demand, as resulted in most existing literature, particularly for developing countries.

To be more specific, the study draws some important findings. First of all, price elasticities on both aggregate and residential are negatively inelastic, as we expect, suggesting that electricity is considered as an essential necessity for life. Moreover, the estimates show that price elasticity of demand for residential is only half as large as that for aggregate and much lower than that for non- 
residential. This finding may highlight three main facts for residential. First, the smaller price elasticity in residential may measure a higher degree of necessity for electricity as compared to the other types of customers. In fact, per capita energy consumption for households is still low at about $252 \mathrm{kWh}$, indicating most households use electricity for basic needs (PLN, 2010). Second, it may explain the lowest substitutability of electricity among the types of customers. Even though there are a few households, especially in rural areas, that have diesel as a substitute for generating units, they withhold utilizing it due to oil price increases and a limitation of petroleum sale for households. Third, the average share of expenditure on electricity is quite low. This note is caused by the large amount of subsidy given to this sector as a result the price for residential is relatively low compared to the other customers. ${ }^{14}$ Nonetheless, price elasticity for non-residential is about two times higher than that of aggregate, suggesting electricity consumption in the sectors other than residential, possibly the industrial sector, have a high degree of responsiveness to the electricity price.

Moreover, income elasticities for aggregate and residential are positive and quite elastic at about 0.6. This brings the idea that income is quite responsive to electricity consumption. For residential, the income elasticity is slightly higher $(0.67)$ than that for aggregate. This again infers low electricity consumption in households, which is mainly for basic needs, thus, higher income will induce the increased electricity consumption level. However, income elasticity is relatively low in non-residential because we may suppose that industrial and commercial have utilized the capital stocks of electrical appliances and machineries with high energy use intensity in the production process.

Furthermore, the impact of additional customers is positive elastic to electricity demand. It brings about the logical explanation that indeed the addition of customers will

\footnotetext{
${ }^{14}$ In 2010, about half of the total amount of subsidy was allocated to residential. The average share of expenditure on electricity is about $3 \%$ based on BPS statistics 2010.
}

increase electricity consumption. Moreover, it estimates that an additional customer impact is unity.In addition, the results become even more intuitive by simulating an inter-region estimation. This estimation is performed by introducing interaction terms between the explanatory variables and a region-indicator dummy variable, namely Java Bali (JB), which considers $\mathrm{JB}$ region as a developed region where most big cities are located and non-Java Bali (NJB) as less developed regions. ${ }^{15}$ The interaction terms allow the estimated parameter to vary and further determine whether elasticities differ between the two regions. Table 3 shows the estimation results using interaction terms. The estimates of lprice, linc, and lcust are the coefficients of respective elasticities for NJB as a basis for the dummy variable (dummy $=0$ ), while the coefficients of D*lpice, D*linc, and D*lcust are the differences between the estimates in the NJB and JB regions.

In general, the study finds different figures between more advanced and less developed provinces. The first finding is that the price elasticities using aggregate and residential data become smaller for JB provinces, thus, differ with the estimates for NJB. On the other hand, price elasticities in NJB are inelastic at -0.21 and -0.09 for aggregate and residential, respectively. These results point out that price factor is not responsive in JB region as opposed to NJB region. This irresponsive effect may come from an actual fact that in more advanced provinces, the real electricity prices are lower than those in less developed regions, and income levels are also stronger. Hence, the relative lower price and stronger income level lead to a smaller share of expenditure on electricity, which in turn generates a profound inelastic price on electricity demand in JB region because any price increase gives little impact on total income and further on electricity consumption. The higher price elasticity in non JB region can also describe the higher degree of substitutability. In fact, the quality of power service outside Java regions is lower as a result of more frequent black-out incidents. Therefore, customers prepare an alternative

\footnotetext{
${ }^{15} \mathrm{JB}$ provinces have a $59 \%$ share of the total population with area around $7 \%$ of the total area.
} 
Table 3. The results of Interregional Regression Using FE

\begin{tabular}{|c|c|c|c|}
\hline \multirow[b]{2}{*}{ Variables } & \multicolumn{3}{|c|}{ Dependent variable: lec } \\
\hline & Aggregate & Residential & Non residential \\
\hline Iprice & $-0.2083 * * *$ & $-0.0869 * * *$ & $-0.3868^{* * *}$ \\
\hline linc & $\begin{array}{c}(0.030) \\
0.6449 * * *\end{array}$ & $\begin{array}{c}(0.023) \\
0.7676^{* * * *}\end{array}$ & $\begin{array}{c}(0.048) \\
0.2107 * * *\end{array}$ \\
\hline & $(0.052)$ & $(0.048)$ & $(0.048)$ \\
\hline Icust & $\begin{array}{c}1.1022 * * * \\
(0.053)\end{array}$ & $\begin{array}{c}0.8719 * * * \\
(0.055)\end{array}$ & $\begin{array}{c}1.1678 * * * \\
(0.052)\end{array}$ \\
\hline D*lprice & $0.2051^{* *}$ & 0.0471 & 0.1890 \\
\hline $\mathrm{D} * \operatorname{linc}$ & $\begin{array}{l}(0.082) \\
0.2831\end{array}$ & $\begin{array}{r}(0.049) \\
-0.4493 * * *\end{array}$ & $\begin{array}{l}(0.172) \\
0.1117\end{array}$ \\
\hline & $(0.239)$ & $(0.104)$ & $(0.165)$ \\
\hline D*lcust & $-0.7401 * *$ & $0.4545 * * *$ & $-0.4500 * *$ \\
\hline Constant & $-11.4246^{* * *}$ & $-12.3278 * * *$ & $-5.1521 * * *$ \\
\hline & $(0.603)$ & $(0.433)$ & $(0.729)$ \\
\hline Observations & 352 & 330 & 330 \\
\hline $\begin{array}{l}\text { R-squared } \\
\text { No of provinces }\end{array}$ & 0.900 & 0.916 & 0.841 \\
\hline 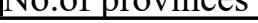 & 32 & & 30 \\
\hline
\end{tabular}

Notes: Standard errors in brackets

$* * *, * *, *$ for $1 \%, 5 \%, 10 \%$ respectively

for that case, for instance providing small generating unit or diesel generator.

This finding is in line with Houthakker, Verlerger, and Shehaan's (1974) conclusion that price elasticity is generally more elastic in regions with a low degree of urbanization. Furthermore, the result of price elasticity for the non-residential sector in JB is significant at about -0.20 (at the $5 \%$ significance level), whereas in NJB it remains at -0.39 . This fact highlights the higher price elasticity in NJB than in JB, meaning that the industrial and commercial sectors in JB are less responsive to the tariff adjustment. The result brings the same idea of Hosoe and Akiyama (2009), showing a more elastic price of electricity demand for the industrial sector in rural regions rather than urban regions.

The inter-regional analysis on the two other determinants of electricity demand is similar to those of national data in which they are all statistically significant. First, for the aggregate level, the income elasticity in the JB region is higher at 0.93 than that of $\mathrm{NJB}$ at 0.64 . This fact indicates lower income levels in NJB compared to JB. In fact, in 2010 , seven provinces in JB contributed about $62 \%$ of the total GDP, while the remaining economy accounted for 26 provinces in NJB. In contrast, it is interesting to note that the income elasticity of demand for residential in JB is smaller (0.32) than that in NJB (0.77). This fact illustrates that households in JB provinces are more intensive in terms of energy utilization for electrical equipment; thus, the electricity consumption is less responsive to higher income level. On the other hand, families in NJB are still utilizing electricity for their basic needs; as a result, the sensitivity of energy consumption is more adaptive as income increases. ${ }^{16}$ For the non-residential sector, the income elasticity in NJB and JB are at the range of 0.21 to 0.32 . This figure points out energy consumption for non-residential (mostly industrial and commercial) gives a modest impact on electricity consumption, and those sectors in $\mathrm{JB}$ are a little bit more responsive to income level change.

Another finding is that the aggregate impact of additional consumers on the energy demand in JB is lower (0.36) than that in NJB (1.10). These estimates may highlight a low $\mathrm{RE}$ in NJB provinces as compared to RE in JB provinces. For the residential sector, we can see that the additional consumer effect is higher in JB provinces. This indicates that a new residential customer in JB is more likely to consume higher energy than one in NJB. The non-residential estimate gives a rather different figure, with the higher elasticity in the NJB region implying that growth of the industrial and commercial sectors in

\footnotetext{
${ }^{16}$ Data of 2010, per capita residential electricity consumption in JB was $60 \%$ higher at $297 \mathrm{kWh}$ than that in NJB at $186 \mathrm{kWh}$.
} 
Table 4. Regression Results: log aggregate (residential) electricity consumption, lec

\begin{tabular}{|c|c|c|c|}
\hline \multirow[b]{2}{*}{ Variables } & \multicolumn{3}{|c|}{ Aogreoate } \\
\hline & $\overline{\mathbf{F E}}$ & OLS & LSDVC \\
\hline L.lec & $0.4519^{* * *}$ & $0.9648 * * *$ & $0.5268 * * *$ \\
\hline & $(0.047)$ & $(0.014)$ & $(0.047)$ \\
\hline lprice & $-0.1607^{* * *}$ & -0.0312 & $-0.1539 * * *$ \\
\hline linc & $0.3099 * * *$ & 0.0169 & $0.2542 * * *$ \\
\hline & $(0.054)$ & $(0.011)$ & $(0.064)$ \\
\hline licust & $0.6049 * * *$ & 0.0153 & $0.5391 * * *$ \\
\hline R-sauared & $(0.070)$ & $(0.015)$ & $(0.068)$ \\
\hline Observations & 320 & 320 & 320 \\
\hline \multirow[b]{2}{*}{ Variables } & \multicolumn{3}{|c|}{ Residential } \\
\hline & $\mathbf{F E}$ & OLS & LSDVC \\
\hline L.lec & $0.6246^{* * *}$ & $0.9604 * * *$ & $0.6870^{* * *}$ \\
\hline lnrice & $(0.037)$ & $\begin{array}{c}(0.014) \\
-0.0767 * * *\end{array}$ & $(0.033)$ \\
\hline Ilprice & $\begin{array}{c}-0.1130 \\
(0017)\end{array}$ & $\begin{array}{r}-0.0 / 6 / 7) \\
(0.017)\end{array}$ & (0.018) \\
\hline linc & $0.2328 * * *$ & $0.0221 * *$ & $0.1879 * * *$ \\
\hline & $(0.040)$ & $(0.010)$ & $(0.045)$ \\
\hline lcust & $0.3734 * * *$ & 0.0122 & $0.3210^{* * *}$ \\
\hline R-squared & $\begin{array}{c}(0.050) \\
0.953)\end{array}$ & & \\
\hline Observations & 300 & 300 & 300 \\
\hline
\end{tabular}

Notes:

L.lec: the lag-1 of dependent variable (lec)

LSDVC: the accuracy of approximation of 3 and initialized by Arellano-Bond estimators

the bootstrapped standard errors within 100 replications

that region brings about a bigger impact on electricity demand.

\section{Dynamic Model}

Alternatively, in order to evaluate the electricity demand behavior within a long-run framework, this paper attempts to simulate the dynamic specification model using a partial adjustment approach with a LSDVC technique. ${ }^{17}$ This estimation is performed using only national level data because interregion estimation will reduce the number of provinces ( $\mathrm{N}$ value), especially in JB $(\mathrm{N}=7)$, leading to biased estimators in the LSDVC technique.

For comparison purposes, this study reports the estimates from the FE and OLS techniques even though we expect the estimates to be biased due to the correlation between the lagged dependent variable and the error term. Accordingly, this paper supports that FE will undervalue the coefficient of the lagged dependent variable as concluded in Nickell (1981), whereas OLS will lead to an

\footnotetext{
${ }^{17}$ Using Stata routine "LSDVC" developed by Bruno,
} 2005 . overestimated result as suggested in Haris, Matyas, and Sevestre (2008).

The regression results presented in Table 4 show the estimates of dynamic model which figuring a similar picture on static model. The results emphasize all variables as the determinants of electricity demand. The result is supportive that the coefficients on all explanatory variables and on the lagged dependent variable bring the expected signs in both the aggregate and residential models. Similar to the static model, the estimates portray low price elasticities. Further, it is straightforward that the aggregate price elasticity shows a higher magnitude compared to the price elasticity for residential. Again, this finding brings about the same idea as in the static model. Nevertheless, by the inclusion of the past electricity consumption, the estimation carries out smaller coefficients on income elasticity and the effect of additional customers. In addition, the coefficient of income and additional customers effects are slightly higher in aggregate rather than in residential, giving similar information as in the static model. 
Table 5 reports the coefficient of the short-run and long-run elasticities for the estimators of LSDVC. The estimated shortrun price elasticities for both aggregate and residential are negatively inelastic. Furthermore, the coefficients of the long-run estimation are higher than those in the short run, illustrating that an increased electricity price or income levels will give higher impacts to the consumption level in the long term. Moreover, it is straightforward that the aggregate price elasticity shows a higher magnitude compared to the price elasticity for residential. Again, these findings bring about the same idea as in the static model.

Table 5. The Short and Long-Run Elasticities specified by Dynamic Model

\begin{tabular}{|l|c|c|c|c|}
\hline \multirow{2}{*}{$\begin{array}{l}\text { Va- } \\
\text { riables }\end{array}$} & \multicolumn{2}{|c|}{ Aggregate } & \multicolumn{2}{c|}{ Residential } \\
\cline { 2 - 5 } & S-R & L-R & S-R & L-R \\
\hline & & & & \\
Price & -0.1539 & -0.3252 & -0.1117 & -0.3569 \\
Income & 0.2542 & 0.5372 & 0.1879 & 0.6003 \\
\hline
\end{tabular}

The results show that the long-run price elasticities are higher at -0.33 and -0.36 for aggregate and residential, respectively. ${ }^{18}$ These highlight a higher degree of responsiveness of consumption behavior to price increase in the future, as we expected. Therefore, policymakers should be reasonably optimistic about the effectiveness of future pricing policies to reduce electricity consumption. Moreover, a steady electricity tariff will unavoidably increase in the future, considering that government will introduce a subsidy reduction program due to the current large amount of subsidy.

In comparison, this study is in line with Saad (2009), analyzing aggregate energy demand in Indonesia. Similarly, first, the estimates show that the long-run price effect are inelastic, while income elasticities are more elastic. Second, this research also finds that the price elasticity in residential is below the aggregate estimation, indicating a highly subsidized tariff in residential sector. Third, income elasticity for residential is nearly

\footnotetext{
${ }^{18}$ The long-run estimates are calculated by dividing the short-run elasticities with 1 minus the coefficients of the lagged dependent variable.
}

the same, about 0.60 , whereas it is only half of Saad's finding for aggregate. All in all, these outcomes suggest the small response of energy consumption regarding a change in electricity price and an even smaller one for the residential sector. Conversely, income elasticities give information on the high responsiveness of energy demand as income levels change.

\section{CONSLUSION}

A research on energy demand behavior is beneficial to support policy analysis in the energy market. However, few studies have been conducted analyzing demand behavior, particularly energy demand, for Indonesia. In this study, static and dynamic panel data estimates are presented for assessing the impacts of economic activity level and price on electricity consumption using data at the province level from 2000 to 2010.

Basically, the estimates suggest that all explanatory variables significantly are the determinants of electricity consumption. As we have hypothesized, income levels drive electricity consumption positively due to an increased necessity for energy, whereas price level withholds consumption level since it affects the ability in purchasing energy. Moreover, the additional number of customers also significantly drives the growth of electricity consumption.

In the static model, this study gives evidence that price elasticity on electricity demand on the aggregate level is quite small at -0.19 and even smaller $(-0.08)$ for residential sector. Moreover, income levels influence responsively on electricity demand at elasticities of 0.61 (aggregate) and 0.67 (residential). These findings can explain the fact that electricity is a necessity and illustrate a low energy consumption in Indonesia, which is mostly used for basic needs. The estimates may also describe a low degree of substitutability for electricity in Indonesia. In addition, the estimated parameters drawn from non-residential regression give a different view of moderately elastic price and inelastic income effect. This result suggests consumption levels in manufacturing and commercial, as the major share of nonresidential consumption, are sensitive to an 
increased price but not responsive to income levels.

Furthermore, by interregional comparison of the estimation, the research gives evidence of differential impacts of income and price level on energy consumption between Java Bali and non-Java Bali provinces. Interestingly, for aggregate and residential data, while price elasticity in NJB is inelastic at -0.20 and -0.09 , it turns to be profoundly inelastic in JB region. Then, income elasticities in JB provinces (aggregate and non-residential) are higher than those in NJB, while they are lower for residential in JB. Regarding the current tariff structure, this fact suggests that electricity consumption in more developed provinces has a very small response on price increase; however, it is affected substantially by income levels. On the contrary, consumption in less advanced regions will be more responsive to tariff adjustment and less sensitive to income levels. However, the results using non-residential data show small differences of price and income elasticity between the two regions.

Similarly, the empirical results of the dynamic model show that in the short term, the price is inelastic in absolute terms, and income is more elastic to demand. Moreover, the results also indicate price elasticity in residential is smaller than that in the aggregate level, as reported in the static model. The long-run price elasticities are more elastic than the short run; however, the magnitudes of parameters are relatively moderate. Thus, an increased electricity price will have a modest effect on the electricity demand. Additionally, the relatively high income elasticities in the long run indicate that increasing income levels will further bring about a substantial increase in electricity consumption.

This empirical work concludes that price elasticity of electricity demand in Indonesia is inelastic and shows, further in the long run, a moderate magnitude in absolute terms. This evidence gives an economic rationale to a tariff adjustment. Moreover, price elasticity of electricity demand in residential sector is even much smaller than in national level. Thus, a higher rates of price increase for residential is plausible. In fact, about half of the amount of subsidy has been compensated for electricity consumption in households. This action may help the government to reduce burden on the national budget as a result of the large amount of electricity subsidy. Then, policymakers may reallocate subsidy to improve electricity supply, such as by constructing new generation units and extending transmission lines; as a result, more people will have access to electricity, regarding low values of ER in most provinces.

In accordance with interregional comparison, the results show the presence of differential impacts of a change in price and income level on energy consumption among provinces. Therefore, policymakers may consider rationalizing current tariff structures based on regional characteristics, as regulated in Law No. 30 of 2009. Based on the findings, government should impose a higher increase of electricity price for Java Bali provinces due to much lower price elasticity compared to the NJB region. For example, a non-subsidized tariff might be reasonably imposed for customers in JB provinces, whereas subsidy may still be necessary for customers in NJB. In addition, government may provide subsidy for consumers in NJB because they are quite responsive to higher price and still utilize energy below the consumption level of JB customers.

With regard to income elasticity, the estimates suggest that income level also significantly affects energy consumption. It is interesting to note that the coefficient for JB is bigger than that for the NJB region. This fact implies that an increased income level in JB will lead to a larger increase of electricity consumption, which in turn will require a larger energy supply as compared to NJB. Therefore, planning and management of the energy supply in JB is more crucial. According to relatively high estimates in the long run, introducing more energy-friendly appliances and machines will be beneficial to support energy conservation programs as income level increases, particularly for JB provinces.

Furthermore, the estimates of additional customers are also elastic. Therefore, policymakers should again establish good strategic planning for the supply side. The findings show that the impact of an additional 
customer on the electricity demand in NJB is about unitary, whereas it is moderate in JB. In accordance with the current acceleration program for ER and the low values of ER in most NJB provinces, these estimates expose a crucial need for energy supply management in NJB.

\section{REFERENCES}

Al-Faris, A. Razak. (2002). The Demand for electricity in the GCC countries. Energy Policy, 30, 117-124.

Alberini, A., Filippini, M. (2011). Response of residential electricity demand to price: the effect of measurement error. Energy Economics 33 (5), 889-895.

Amusa, H., Amusa, K., Mabugu, R. (2009). Aggregate demand for electricity in South Africa: An analysis using the bounds testing approach to cointegration. Energy Policy, $37,4167-4175$.

Anderson, P. Kent. (1973). Residential demand for electricity: Econometric estimates for California and the United States. The Journal of Business, 46, 526-553.

Anderson, T. and Hsiao, C. (1982). Formulation and estimation of dynamic models using panel data. Journal of Econometrics, 18, 570-606.

Arellano, M. and Bond, S. (1991). Some tests of specification for panel data: Monte Carlo evidence and an application to employment equations. Review of Economic Studies, 58, 277-297.

Beenstock, M., Ephraim, G., Dan, N. (1999). The demand for electricity in Israel. Energy Economics, 21, 168-183.

Bernstein, M.A., Griffin, J.M. (2006). Regional Differences in the Price-Elasticity of Demand for Energy. The Rand Corporation Technical Report.

Blazquez, L., Boogen, N., Filippini, M. (2013). Residential electricity demand in Spain: New empirical evidence using aggregate data. Energy Economics, 36, 648-657.

Blundell, R., Bond, S. (1998). Initial conditions and moment restrictions in dynamic panel data models. Journal of Econometrics, 87 (1), 115-143.

BPK RI. Examination Report on Electricity Subsidy (from 2000-2017).

Brenton, P. (1997). Estimates of the demand for energy using cross-country consumption data. Applied Economics, 29, 851-859.

Bruno, G. F. S.(2005). Estimation and inference in dynamic unbalanced panel-data models with a small number of individuals. The Stata Journal, 5(4), 473-500.

De Vita., G, K Endresen., L. C. Hunt. (2006). An empirical analysis of energy demand in Namibia. Energy Policy, 34, 3447-3463.

Dahl, C. (1993). A survey of energy demand elasticities for developing world. The Journal of Energy and Development, 18(1), $1-47$.

Dahl, C. A. (2011). A global survey of electricity demand elasticities. The 34th IAEE International Conference: Institutions, Efficiency and Evolving Energy Technologies, June 19-23, 2011. At Stockholm School of Economics, Sweden.

Dergiades, T., Tsoulfidis, L. (2008). Estimating residential demand for electricity in the United States, 1965-2006. Energy Economics, 30, 2722-2730.

Filippini, M. (1999). Swiss residential demand for electricity. Applied Econometrics Letters, 6(8), 533-538.

Filippini, M., Pachauri, S. (2004). Elasticities of electricity demand in urban Indian households. Energy Policy, 32, 429-436.

Halicioglu, F. (2009). Residential electricity demand dynamics in Turkey. Energy Economics, 29, 199-210.

Haris, M., Matyas, S.L., Sevestre, P. (2008). Dynamic Models for Short Panels, In: Matyas, Sevestre (Eds.), The Econometrics of Panel Data (3rd ed.). Springer-Verlag, Darmstadt, Germany, 249-278.

Holtedahl, P., Joutz, F.L. (2004). Residential electricity demand in Taiwan. Energy Economics, 26(2), 201-224.

Hosoe, N., Akiyama, S. (2009). Regional electric power demand elasticities of Japan's 
industrial and commercial sectors. Energy Policy, 37, 4313 - 4319.

Houthakker, H. S. (1951). Some calculations of electricity consumption in Great Britain. Journal of the Royal Statistical Society, 114, 351-371.

Houthakker, H.S., Taylor, L.D. (1970). Consumer demand in the United States (2nd ed.). Cambridge, MA: Harvard University Press.

Houthakker, H.S., Verleger, P.K., Shehaan, D.P. (1974) Dynamic Demand Analyses for Gasoline and Residential Electricity. American Journal of Agricultural Economics, 56(2), 412-418.

Ibrahim, B., Hurst, C. (1990). Estimates of energy and oil demand functions. A study of thirteen developing countries. Energy Economics, 93-101.

Jamil, F., Ahmad, E. (2011). Income and price elasticities of electricity demand: Aggregate and sector-wise analyses. Energy Policy, 39, 5519-5527.

Judson, R. A. and A. L. Owen. (1999). Estimating dynamic panel data models: a guide for macroeconomists. Economics Letters, 65, 9-15.

Kiviet, J. F. (1995). On bias, inconsistency, and efficiency of various estimators in dynamic panel data models. Journal of Econometrics, 68(1), 53-78.

Krisnamurthy, C., and Kristrom, B. (2013). Energy demand and income elasticity: a cross-country analysis (CERE Working paper 2013:5). Retrieved July 5, 2014, from http://www.cere.se/documents/wp/2013/ CERE_WP2013-5.pdf

Narayan, P.K., Smyth, R. (2005). The residential demand for electricity in Australia: and application of the bounds testing approach to cointegration. Energy Policy, 33, 467-474.

Narayan, P.K., Smyth, R., Prasad, A. (2007). Electricity consumption in G7 countries: a panel cointegration analysis of residential demand elasticities. Energy Policy, 35(9), 4485-4494.
Nickell, S. J. (1981) Biases in dynamic models with fixed effects. Econometrica, 49(6), 1417-1426.

Nordin, J.A. (1976). A proposed modification of Taylor's demand analysis: comment. Bell J. Econ. 719-721.

Paul, A., Myers, E., Palmer, K. (2009). A partial adjustment model of U.S. electricity demand by region, season, and sector. Resource for the Future Discussion Paper 08-50, Washington, DC, April.

Pesaran, M.H., Smith, R., Akiyama, T. (1998). Energy demand in Asian economies. Oxford University Press, Oxford.

Pindyck, R.S. (1979). The structure of world energy demand. MIT Press, Cambridge, Massachusetts and London, England.

Pitt, M.M. (1985). Estimating industrial energy demand with firm-level data: the case of Indonesia. Energy Journal, 6 (2), 25-39.

PT PLN (Persero). Annual Report (from 20002015).

Saad, S. (2011). Underlying energy demand trends in South Korean and Indonesian aggregate whole economy and residential sectors. Energy Policy, 39, 40-46.

Shin J. S. (1985). Perception of price when price information is costly: evidence from residential electricity demand. The Review of Economics and Statistics, 67(4), 591-598.

Silk, J.I., Joutz, F.L. (1997). Short and long run elasticities in US residential electricity demand: a co-integration approach. Energy Economics, 19, 493-513.

Wooldridge J. M. (2009). Advanced Panel Data Methods. Introductory Econometrics: A modern approach (4th ed., pp. 481-496). Canada: South-Western Cengange Learning.

World Bank.(2011). Multipolarity: The New Global Economy. Global Development Horizons 2011. 


\section{APPENDICES}

\section{Table A}

\section{Selected Research}

\begin{tabular}{|c|c|c|c|}
\hline Study/Country & Price elasticity & $\begin{array}{c}\text { Income elas- } \\
\text { ticity }\end{array}$ & Method/data span \\
\hline $\begin{array}{l}\text { Blazquez et al. (2013), } \\
\text { Spain (residential) }\end{array}$ & $\begin{array}{l}\text { Short run: }-0.07 \\
\text { Long run: }-0.19\end{array}$ & $\begin{array}{l}\text { Short run: } 0.23 \\
\text { Long run: } 0.61\end{array}$ & $\begin{array}{l}\text { GMM estimator, provincial } \\
\text { panel data, 2000-2008 }\end{array}$ \\
\hline $\begin{array}{l}\text { Jamil and Ahmad (2011), Pakistan } \\
\text { (aggregate and by sectors) }\end{array}$ & $\begin{array}{l}\text { Aggregate: } \\
\text { Short run: }-0.07 \\
\text { Long run: }-1.27 \\
\text { Residential: } \\
\text { Short run: } 0.07 \\
\text { Long run: }-1.22\end{array}$ & $\begin{array}{l}\text { Aggregate: } \\
\text { Short run: } 0.32 \\
\text { Long run: } 1.56 \\
\text { Residential: } \\
\text { Short run: } 0.49 \\
\text { Long run: } 1.97\end{array}$ & $\begin{array}{l}\text { VAR and ECM, annual time } \\
\text { series, 1970-2005, }\end{array}$ \\
\hline $\begin{array}{l}\text { Nakajima (2010), } \\
\text { Japan (residential) }\end{array}$ & -1.13 & 0.60 & $\begin{array}{l}\text { Group-mean DOLS, annual } \\
\text { panel, 1975-2005 }\end{array}$ \\
\hline $\begin{array}{l}\text { Halicioglu (2009), Turkey (resi- } \\
\text { dential) }\end{array}$ & $\begin{array}{l}\text { Short run: }-0.33 \\
\text { Long run: }-0.52\end{array}$ & $\begin{array}{l}\text { Short run: } 0.44 \\
\text { Long run: } 0.70\end{array}$ & $\begin{array}{l}\text { ARDL, annual time series, } \\
1968-2005\end{array}$ \\
\hline $\begin{array}{l}\text { Amusa et al. (2009), South Africa } \\
\text { (aggregate) }\end{array}$ & $\begin{array}{l}\text { Short run: } 0.04 \\
\text { Long run: } 0.30\end{array}$ & $\begin{array}{l}\text { Short run: } 0.22 \\
\text { Long run: } 1.67\end{array}$ & $\begin{array}{l}\text { ARDL, annual time series, } \\
1960-2007\end{array}$ \\
\hline $\begin{array}{l}\text { Derigiades and Tsoulfidis (2008), } \\
\text { USA (residential) }\end{array}$ & $\begin{array}{l}\text { Short run: }-0.39 \\
\text { Long run: }-1.06\end{array}$ & $\begin{array}{l}\text { Short run: } 0.10 \\
\text { Long run: } 0.27\end{array}$ & $\begin{array}{l}\text { ARDL, annual time series, } \\
\text { 1965-2006 }\end{array}$ \\
\hline $\begin{array}{l}\text { De Vita et al. (2006), Namibia (ag- } \\
\text { gregate) }\end{array}$ & Long run: -0.298 & $\begin{array}{l}\text { Long run: } \\
0.589\end{array}$ & $\begin{array}{l}\text { Cointegration method, quar- } \\
\text { terly time series, 1980-2002 }\end{array}$ \\
\hline $\begin{array}{l}\text { Narayan and Smyth (2005), Aus- } \\
\text { tralia (residential) }\end{array}$ & $\begin{array}{l}\text { Short run: }-0.26 \\
\text { Long run: } \\
-0.54 \text { to }-0.47\end{array}$ & $\begin{array}{l}\text { Short run: } \\
0.01 \text { to } 0.04 \\
\text { Long run: } \\
0.32-0.41\end{array}$ & $\begin{array}{l}\text { Cointegration and error cor- } \\
\text { rection, annual time series, } \\
1969-2000\end{array}$ \\
\hline $\begin{array}{l}\text { Filippini and Pachauri (2004), } \\
\text { India (residential) }\end{array}$ & -0.42 to -0.29 & 0.60 to 0.64 & $\begin{array}{l}\text { Panel data estimation, monthly } \\
\text { surveys, 1993-1994 }\end{array}$ \\
\hline $\begin{array}{l}\text { Holtedahl and Joutz (2004), Tai- } \\
\text { wan (residential) }\end{array}$ & -0.15 & 1.04 to 1.57 & $\begin{array}{l}\text { Cointegration and error cor- } \\
\text { rection, annual time series, } \\
1955-1995\end{array}$ \\
\hline $\begin{array}{l}\text { Al-Faris (2002), GCC countries } \\
\text { (aggregate) }\end{array}$ & $\begin{array}{l}\text { Short run: } \\
-0.18 \text { to }-0.04 \\
\text { Long run: } \\
-3.39 \text { to }-0.82\end{array}$ & $\begin{array}{l}\text { Short run: } \\
0.02-0.70 \\
\text { Long run: } \\
0.33-5.39\end{array}$ & $\begin{array}{l}\text { Cointegration approach, an- } \\
\text { nual time series data, } \\
1970-1997\end{array}$ \\
\hline $\begin{array}{l}\text { Silk and Joutz (1997), United } \\
\text { States (residential) }\end{array}$ & Long run: -0.48 & Long run: 0.52 & $\begin{array}{l}\text { Cointegration approach, an- } \\
\text { nual time series, 1949-1993 }\end{array}$ \\
\hline
\end{tabular}




\section{Table B}

\section{Data Sources}

\begin{tabular}{|l|l|l|}
\hline \multicolumn{1}{|c|}{ Variable } & \multicolumn{1}{|c|}{ Description } & \multicolumn{1}{|c|}{ Source } \\
\hline $\begin{array}{l}\text { Electricity consumption } \\
\text { (GWh), EC }\end{array}$ & $\begin{array}{l}\text { Aggregate: total electricity consumption } \\
\text { (GWh) } \\
\text { Residential: residential electricity con- } \\
\text { sumption (GWh) }\end{array}$ & PLN. Annual Report \\
\hline $\begin{array}{l}\text { Real income } \\
\text { (2000 billion rupiah), INC }\end{array}$ & $\begin{array}{l}\text { Aggregate: constant GRDP with oil and } \\
\text { gas at 2000 (billion Rp) } \\
\text { Residential: constant provincial private } \\
\text { expenditure at 2000 (billion Rp) }\end{array}$ & $\begin{array}{l}\text { Central Bureau of Statistics } \\
\text { (Badan Pusat Statistik) }\end{array}$ \\
\hline $\begin{array}{l}\text { Real average price of elec- } \\
\text { tricity } \\
\text { (2000 rupiah/kWh), P }\end{array}$ & $\begin{array}{l}\text { Aggregate: total revenue from sales } \\
\text { divided by electricity consumption, } \\
\text { deflated by GRP deflator (Rp/kWh) } \\
\text { Residential: total revenue in residential } \\
\text { sector divided by electricity consump- } \\
\text { tion in residential sector, deflated by } \\
\text { CPI (Rp/kWh) }\end{array}$ & $\begin{array}{l}\text { Own calculation with data of: } \\
\text { average electricity price for ag- } \\
\text { gregate and residential from the } \\
\text { Annual Report of PT PLN and } \\
\text { tained from Central Bureau of } \\
\text { Statistics. }\end{array}$ \\
\hline $\begin{array}{l}\text { The number of customers } \\
\text { (million), CUST }\end{array}$ & $\begin{array}{l}\text { Aggregate: the total number of custom- } \\
\text { ers } \\
\text { Residential: the number of residential } \\
\text { customers }\end{array}$ & PT PLN. Annual Report \\
\hline
\end{tabular}

\section{Table $\mathbf{C}$}

\section{Descriptive Statistics of Regional Data}

Java Bali region:

\begin{tabular}{|l|c|c|c|c|}
\hline \multicolumn{1}{|c|}{ Variables } & Mean & Std. Dev. & Minimum & Maximum \\
\hline Aggregate & & & & \\
\hline Electricity consumption (GWh) & 12239.81 & 8334.10 & 945.19 & 30720.99 \\
\hline Electricity price (Rp/kWh) & 347.81 & 56.77 & 246.80 & 472.29 \\
\hline GDRP (billion 2000 Rp) & 151160.10 & 117458 & 13480.6 & 395664.50 \\
\hline Number of customers & 3376692 & 2546379 & 573649 & 8206806 \\
\hline Residential & & & & \\
\hline Electricity consumption (GWh) & 4393.79 & 2999.42 & 554.42 & 11617.13 \\
\hline Electricity price (Rp/kWh) & 300.17 & 70.41 & 172.63 & 464.01 \\
\hline Private expenditures (billion 2000 Rp) & 91743.45 & 73203.55 & 7355 & 243827.20 \\
\hline Number of customers & 3149455 & 2393625 & 516609 & 7740066 \\
\hline
\end{tabular}

Non-Java Bali region:

\begin{tabular}{|l|c|c|c|c|}
\hline \multicolumn{1}{|c|}{ Variables } & Mean & Std. Dev. & Minimum & Maximum \\
\hline Aggregate & & & & \\
\hline Electricity consumption (GWh) & 912.09 & 1035.83 & 40.18 & 6636.45 \\
\hline Electricity price (Rp/kWh) & 353.14 & 76.38 & 201.81 & 546.77 \\
\hline GDRP (billion 2000 Rp) & 26839.97 & 26748.33 & 1473.27 & 118640.9 \\
\hline Number of customers & 450374 & 443827 & 47720 & 2551931 \\
\hline Residential & & & & \\
\hline Electricity consumption (GWh) & 518.02 & 494.20 & 29.04 & 3073.58 \\
\hline Electricity price (Rp/kWh) & 292.67 & 66.65 & 178.39 & 447.66 \\
\hline Private expenditures (billion 2000 Rp) & 13256.32 & 12977.24 & 1230.80 & 74120.4 \\
\hline Number of customers & 452721 & 433761 & 44315 & 2391177 \\
\hline
\end{tabular}




\section{Partial adjustment mechanism}

Partial adjustment approach assumes that the change in the log of actual demand between any two periods $t-1$ and $t$ is only some fraction $(\lambda)$ of the difference between the logarithm of actual demand in period $t-1$ and the logarithm of the long-run equilibrium demand in period t. Formally, , where $0<\lambda<1$

where $=$ reflects the current elasticities and adjusts partially to changes in the desired (LR) estimates. Therefore, we can interpret as follows,

SR elasticities $=$ LR elasticities $(\beta$ or $\gamma) *$ adjustment factor $(\lambda)=$ the estimates $(\lambda \beta$ or $\lambda \gamma)$ and LR elasticities $=$ the estimates $(\lambda \beta$ or $\lambda \gamma) /(1-\lambda)$ 
20 | Jurnal Ekonomi dan Pembangunan Vol 26, No. 1, 2018 